\title{
THE TRANSFIGURATION ERROR IN ROWLING'S HARRY POTTER AND THE CHAMBER OF SECRET
}

\author{
Siegfrieda A.S. MursitaPutri \\ siegfrieda@ukrida.ac.id \\ Universitas Kristen KridaWacana \\ Jakarta Barat, DKI Jakarta, Indonesia
}

\begin{abstract}
Translator is always given two options in translating literary works. Either they can pick formal orientation, or pick dynamic orientation. Both orientations have different effect for readers. Harry Potter and the Chamber of Secret is one best-selling novel written by J.K. Rowling. Her work in the series is known for the play of words. This paper proposes other version of translation by exposing several sentences taken from the novel. The result shows that the Indonesian translation of Harry Potter and the Chamber of Secret is quite good to read. Unfortunately, there are still some inappropriate words in the target language which can change the effect and the tenseness of the story. The sentence structures also need to be rearranged. This was because the translator faces the option to be faithful but ugly or to be beautiful but inaccurate. This can be solved by trying to find as close as possible the appropriate equivalence and not only being formal-oriented in the translation process.
\end{abstract}

Keywords: Translation assessment, translation orientation, Harry Potter

\section{INTRODUCTION}

According to Bell, translation is the replacement of a representation of a text in one language by a representation of an equivalent text in a second language (1997:6). There are difficulties in translating process: loss, gain \& untraslatability, equivalence vs. non-equivalence and cultural differences. Bell made the problem of equivalence very plain: translated text can be equivalent in different degrees, based on the context, register and types of translation. To shift from one language to another is to alter the forms. Unfortunately, there is no absolute synonymy between words in the same language. Therefore, it is not surprising if we find a lack of synonymy or 'strange words' in the target language.

Nida (1964) mentioned two basic orientations in translating. Nida quoted from Belloc, that there are no such things as identical equivalents. Translator has the options to focus on finding the closest possible equivalence: formal or dynamic - or according to Bell functional.

Formal equivalence focuses on the message itself, in both form and content. Seen from this orientation, the message in the target language should match as closely as possible the different elements in the source language. So, in this orientation the message in the target culture is compared constantly with the message in the source culture to determine standards of accuracy and correctness (2002:156). In other word, this orientation is word-for-word translation or literal translation (Bell, 1997:7).

On the other hand, a translation which is dynamic orientation - or functional - is based upon "the principle of equivalent effect". In this orientation, the relationship between target culture and message should be substantially the same as that which existed between the source culture and message (2002:156). Or in other word, it is meaning-for-meaning translation or free translation (Bell, 1997:7)

Translators must face those two orientations to choose: pick formal and then criticized for the ugliness of a faithful, or pick dynamic or functional and then being accused for the inaccuracy of a beautiful (Bell, 1997:7).

Larson stated that the best translation is the one which uses the normal language forms of the target language, communicates as much as possible to the target language readers the same meaning that was understood by the speakers of the source language, and maintains the dynamics of the original source language text - or evoke the same response as the source text attempted to evoke (1984:5).

Harry Potter and the Chamber of Secret is considered as a prose. There are 
six general rules for the translator of prose texts (Belloc in Bassnett, 1991:116-117):

1. The translator should consider the work as an integral unit and translate in sections. The content and form must be treated as a unity.

2. The translator should render idiom by idiom. What is emphasized is the meaning of the idiom, not just the form of the idiom.

3. The translator must render intention by intention. The translator must not be concerned with the structure of the sentences only.

4. The translator must be careful with the sentences which seem to correspond in both SL and TL but actually they do not.

5. Translating a prose text means telling the exact SL in the TL (adaptation or faithful translation).

6. The translation should not embellish or add details.

Machali mentioned some aspects in translation assessment: there is no shifting in communicating the message in the source language, equivalence (linguistically, semantically and pragmatically) and transferring accurately in the target language (2000:115). The criteria required are whether the translation is flowing or not, the terminologies are transferred correctly or not and the equivalences are appropriate or not.

\section{THEOITICAL REVIEW}

Harry Potter and the Chamber of Secret is one series of Harry Potter's adventure in Hogwarts School of Witchcraft and Wizardry by J.K. Rowling. This story is chosen because Rowling can create "a new world" in teenagers and adults with her "Magic" around the world. Introducing a world of impossibilities and imaginations, she creates the magic fever in teenagers around the world. Rowling, according to her publisher, has won the Hugo Award, the Bram Stoker Award, the Whitbread Award for Best Children's Book, and a special certificate for being a three-year winner of the Smarties Prize. Her book Harry Potter and the Goblet of Fire and Harry Potter and the Order of the Phoenix won the title of "the fastest-selling book in history". Besides all those honours, each title of Harry Potter's adventure has been number one on The New York Times, USA Today, and Wall
Street Journal bestseller lists

(http://www.scholastic.com/

harrypotter/author/ retrieved on 11

December 2006).

Harry Potter and the Chamber of Secret is about Harry's second year in Hogwarts. As usual, before the new academic year Harry had to stay in his uncle's house, Vernon Dursley, in Privet Drive number four. The Dursleys were so mean and hideous to Harry, even forgot his twelfth birthday! Instead of talking about Harry's birthday, Vernon was talking about the stupid dinner party with the Masons to make the biggest deal of his career. Therefore, Harry wanted to get back to Hogwarts. But just as he's packing his bags, Harry receives a warning from a strange, impish creature named Dobby who says that if Harry returns to Hogwarts, disaster will strike.

This story has some certain characteristics and needs special effort in translating the text since Rowling has created new words, used unusual words and sometimes made rhymes in Harry Potter. As a result, Harry Potter is rather difficult to translate considering that it might be hard to find the appropriate equivalence in the target text, in this case Indonesian.

The result of the translation assessment is 1.3. From the translation, I see that the translator tends to use formal orientation, since she had no right in adapting the whole story into something 'Indonesian'. On the other hand, the translation did not give the same effect to the reader. It is tenser to read the English version than the Indonesian version. The reasons were because some words are not precisely translated and the sentence structures are not well-arranged. Only some of them related to cultural problems.

\section{DISCUSSION}

From the analysis below we will see the parts which are not precisely translated and the structure are not well-arranged. The examples are shown in a format of Source Text (ST) and its Target Text (TT).

Example 1:

ST: ..., an argument had broken out over breakfast at number four, Privet Drive. Mr. Vernon Dursley had been woken ... 
TT:

Bukanuntukpertamakalinyapertengkar anmeledak di mejamakanrumah Privet Drive nomorempat. Sebelumnya Mr. Vernon Dursley .... .

From example 1, the an argument had broken out over breakfast at number four, Privet Drive in the ST would be better if translated into terjadi pertengkaran di meja makan saat sarapan di rumah yang terletak di Privet Drive nomor empat. Then the word Mr. Vernon Dursley should be translated into Pak Vernon Dursley or simply Vernon Dursley considering in Indonesian people will not use the term "Mister". It is better to use pak or simply his name or, if the translator wants to maintain the cultural closeness, the word Mister is italicized.

Example 2:

ST: "Third time this week!" he roared across the table. "If you can't control that owl, it'll have to go!"

TT:

"Untukketigakalinyamingguini!"

raungnya. "Kalau kau tidakbisamengontrolburunghantuitu, diaharuspergi!"

From example 2, the translator should find the right expression of third time this week and it'll have to go. Third time this week can be expanded into It has been three times this week your owl .... Therefore, the right translation should be Sudah tiga kali dalam minggu ini! Then it'll have to go should not be simply translated into dia harus pergi since it here means the owl which is animal and go here must be get out here with force. Also, animal can not go by itself, can it? Especially in this case, Vernon was angry because of the owl). Then the proper translation should be burung hantu itu akan kubuang.

Example 3:

ST: Dudley, who was so large his bottom drooped over either side of the kitchen chair, .... .

TT:

Dudley,

yang

luarbiasagemuknyasampaipantatnyam elimpah di kiri-kanankursidapur, ... .

From example 3, the sentence structure should be simple like yang badannya sangat gemuk sampai-sampai kursi dapur tidak mampu menopang pantatnya yang besar. It is because in Indonesian, something which can melimpah is liquid.

\section{Example 4:}

ST: "I WARNED YOU! I WILL NOT TOLERATE MENTION OF YOUR ABNORMALITY UNDER THIS ROOF!"

TT: "KUPERINGATKAN KAU! AKU TAK MENGIZINKAN KEABNORMALANMU DISEBUT-SEBUT DI BAWAH ATAP INI!"

From example 4, the translator tends to do word-for-word translation. Abnormality here refers to the Harry's abnormality because he is a wizard. It is better to translate it into kemampuan sihirmu or halhal yang berbau sihir. Under this roof refers to house or place to live in. Therefore, the appropriate translation should be dalam rumah ini. Or if we restructure the sentence it will be Aku tak mengizinkan kau menyebut hal-hal berbau sihir dalam rumah ini!

\section{Example 5}

ST: All Harry's spellbooks, his wand, robes, cauldron, and top-of-the-line Nimbus Two Thousand broomstick had been locked in a cupboard....

What did the Dursleys care if Harry lost his place on the House Quidditch team....

Uncle Vernon had even padlocked Harry's owl, Hedwig, inside her cage, ...

TT: Semuabukupelajaran Harry, tongkat, jubah, kuali, dansapu top Nimbus DuaRibu-nyadikunci di dalamlemari....

ApapedulinyakeluargaDursleykalau Harry kehilangantempat di tim Quidditch asramanya....

Paman

Vernon

bahkantelahmenggembokburunghantu

Harry, Hedwig, ...

From example 5, the translator chose inappropriate words in the TT. Broomstick there must be translated into sapu terbang since the story is about witches and wizards world which is associated with flying brooms. The expression lost his placemight be has different interpretation in the TT, in this case Indonesian. Lost his place is better translated into didepak dari or kehilangan 
posisinya sebagai seeker considering that the reader has known Harry's position on the House Quidditch team. Or if they have not, the description of Quidditch must be told in other part of the novel (Rowling tends to explain about Quidditch in the chapter when the game is begun). Later, the word padlocked is mistranslated into menggembok. Even in Indonesian the word meaning is gembok, the word should not be translated literally since menggembok in Indonesian should be followed by something inanimate, like door or gate. It is better to translate it into mengurung since it is followed by animate object.

Example 6:

ST: Harry looked nothing like the rest of the family...

TT: Tampilan Harry samasekali lain darikeluarganya...

From example 6, Harry looked nothing like the rest of the family should be translated faithfully into Secara fisik Harry sama sekali berbeda dari keluarga Dursley.

\section{Example 7:}

ST: ..., never understanding why he kept making odd things happen without meaning to, ...

TT:

takpernahmemahamikenapadiatakputusputusmembuathal-

halanehterjadiwalaupundiatakbermaksud melakukannya. ...

From sentence 32, kept making odd things happen should be simply translated into kenapa dia terus menerus membuat halhal aneh since "keep making" can be expanded into "go on making".

\section{Example 8}

ST: And then, exactly a year ago, Hogwarts had written to Harry, ...

TT: Dan kemudian, tepatnyasetahun yang lalu, Hogwarts menulissuratkepada Harry, ...

The word had written in example 8 should be translated into mengirim surat since the effect is more rousing using the word mengirim instead of menulis.
Example 9:

ST: ... "The Masons don't know anything about you and it's going to stay that way. When dinner's over, you take Mrs. Mason back to the lounge for coffee, ...

TT: ... "Suami-istri Mason samasekalitidaktahumenahutentang kau danharustetapbegitu. Setelahmakanmalamselesai, kaubawaMrs Mason kembalikeruangtamuuntukminum kopi, ..."

The Masons in example 9 should not be translated into suami-istri Mason since in the source language the followed by plural family names refer to the family member of the name mentioned. Therefore, The Masons should be translated into Keluarga Mason, since - if I'm not mistaken - the Masons also took their boy with them. In it's going to stay that way the translator translated it literally instead of tidak boleh tahu. Later the word you take was also translated literally into kaubawa. Since a person can not be 'brought' it is better to translate it into kauajak or ajaklah.

\section{Example 10}

ST: Not that his whole year at Hogwarts had been fun. ... Harry kept waking in the night, drenched in cold sweat, wondering where Voldemort was now,

TT:

Bukanberartidiasenangterussepanjangw aktu di Hogwarts. ... , Harry masihterbangun di malamhari, mandi keringatdingin, bertanya-tanyadalamhati di mana Voldemort sekarang, ...

In example 10, the translator misinterpret the concept of not that his whole year at Hogwarts had been fun. If we see the meaning of the sentence is like this expanded one: Last year Harry was in the first grade. He spent his first year in Hogwarts with fun and danger. So the meaning of his whole year refers to his first year in Hogwarts not sepanjang waktu (all the time as if he had been in Hogwarts for several years). Therefore, the translation should be Bukan berarti dia senang terus selama tahun pertamanya di Hogwarts. Then the phrase drenched in cold sweat. 
Seeing from the meaning, drenched should be translated in passive. Therefore the translation should be bermandikan keringat dingin since in Indonesian mandi is an active verb and it is impossible that someone, intentionally, mandi keringat dingin.

\section{CONCLUSION}

From the analysis above, we can conclude that the Indonesian translation of Harry Potter and the Chamber of Secret is quite good to read. Unfortunately, there are still some inappropriate words in the target language which can change the effect and the tenseness of the story. The sentence structures also need to be rearranged. This was because the translator faces the option to be faithful but ugly or to be beautiful but inaccurate. This can be solved by trying to find as close as possible the appropriate equivalence and not only being formaloriented in the translation process.

\section{REFERENCES}

Bassnett, S. (1991). Translation Studies. London: Routledge.

Bell, R. T. (1997). Translation and Translating: Theory and Practice. New York: Longman Ltd.

Larson, M. L. (1984).Meaning-based Translation: A Guide to Cross-language Equivalence. Lanham: University Press of America.

Machali, R. (2000). PedomanBagiPenerjemah. Jakarta: PT Grasindo.

Nida, E. (2002). "Principles of Correspondence" in The Translation Studies Reader ( $\left.2^{\text {nd }} e d\right)$. 1964. ed. Lawrence Venuti. New York: Routledge.

Harry Potter: Meet J.K. Rowling (2006). Retrieved from http://www.scholastic.com/harrypotter/ author 